\title{
In-depth Study of Pharmacology Teaching Reform Based on Ability Training under the Framework of American DQP
}

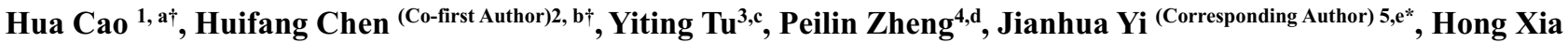 \\ (Corresponding Author) 6,f*, Yuqi Ning (Corresponding Author) 7, $\mathrm{g}^{*}$ \\ $\dagger$ Author Contributions $\dagger$ Huifang Chen is Co-first Author; Huifang Chen and Hua Cao contribute equally.
}

Notes: The authors declare no competing financial interest.

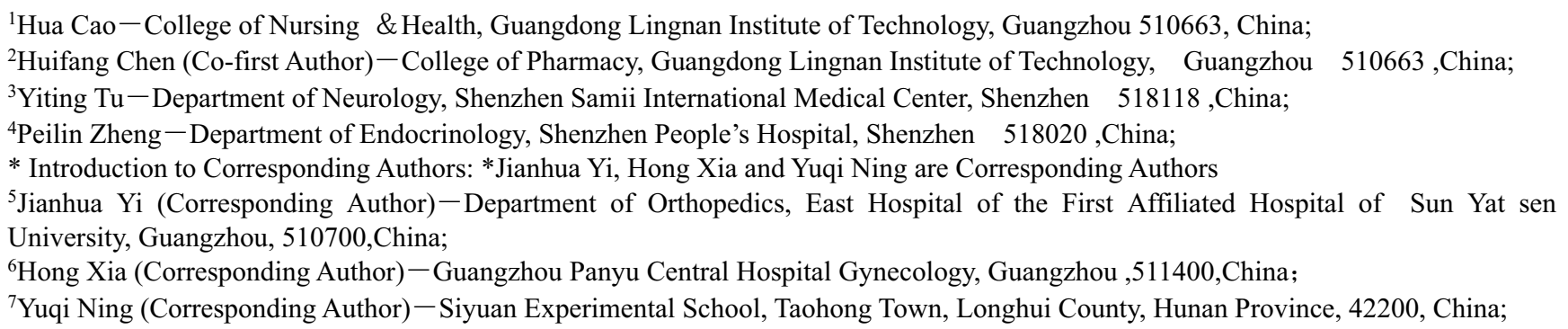

\begin{abstract}
With the rapid development of economy in China, the pharmaceutical industry rises quickly. Although China's higher medical vocational education develops fast, there are many problems in the current traditional teaching mode and curriculum system, which cannot meet the needs of students. How to reform the education mode under the background of informatization is becoming the focus of vocational education reform in recent years. In this paper, we discussed the teaching effectiveness of DQP framework, an international advanced talent training system of higher vocational education. We found that by choosing reasonable integration of teaching content, different teaching methods, it is in line with the requirements of the times. It facilitates the establishment of pharmacology curriculum standards, the organization of the compilation of pharmacology textbooks which contains the latest knowledge, the use of student-centered flipped classroom teaching mode to improve students' autonomous learning ability, etc.
\end{abstract}

\section{Analysis of problems in pharmacology teaching in the past few years}

In recent years, with the rapid development of China's economy, the pharmaceutical industry develops quickly, resulting in the growing demands for higher vocational education. Pharmacology is one of the main courses of pharmacy, clinical medicine and nursing. It is also a compulsory course for most pharmaceutical majors, such as drug management, medical technology, medical imaging, health products and nutrition. Compared with other courses, pharmacology is more abstract in theory, more complex in knowledge, more boring in content, which is easy to cause students' anxiety. Traditional classroom teaching is monotonous, and students memorize knowledge passively and mechanically. In the teaching process, there are problems such as tight school hours and multiple content, which is considered to be a difficult course not only for teaching but also for learning [1]. With the continuous development of medical health, pharmacology is becoming more and more important.
For nursing students who will be engaged in clinical nursing in the future, they must not only have deep knowledge of pharmacotherapy, but also deal with clinical practice, which requires in-depth understanding of clinical practice. However, although most of the previous textbooks of higher vocational colleges are strictly adapted to undergraduate textbooks, the relationship between them is very rigid. Medical courses, pharmacy theory courses, and experimental course modules are clearly separated, resulting in the difficulties to form comprehensive training ${ }^{[2]}$. Therefore, we must proceed from the essential goals of pharmacology teaching in higher vocational colleges, and choose different teaching methods according to the content and characteristics of the clinical nursing situation, the actual situation of each student, so as to teach students in accordance with their aptitude. This article is mainly for the research of pharmacology teaching reform in higher vocational colleges, seeking a new ability-oriented teaching mode under the framework of the American DQP degree, and training higher vocational professionals with higher pharmacology professional capabilities to meet social needs. 


\section{An overview of the DQP framework in the United States}

The American DQP degree qualification framework (Degree Qualifications Profile, abbreviated as DQP) is a set of "reference benchmarks" system used by American institutions of higher learning to design degree curriculum systems. It has been evaluated by the Association of American Colleges and Universities (AAC\&U) and the National Institute for Learning Outcomes Assessment (NILOA) and other institutions. Till 2016, more than 400 American colleges and universities have applied DQP. DQP involves associate, bachelor and master degrees. It aims to provide a unified ability level requirement for the cultivation of various fields of degree. It requires that the certified majors must: clarify that students have qualitative and quantitative learning outcomes, that is, graduation requirements; focus on students; specify the learning ability requirements of the five learning areas of the associate degree in higher vocational under the framework of DQP, and evaluate the learning outcomes. The DQP degree qualification framework in the United States can provide a good reference for the construction of a modern vocational education system in China ${ }^{[3]}$.

\subsection{DQP's five learning areas.}

DQP proposes five fields of study. The requirements for associate degrees in vocational education in each field are as follows:

2.1.1 Professional knowledge. To interpret the structure, types and timing of professional learning areas through tools, techniques, methods and terminology of professional learning areas; to investigate common but complex problems in learning areas by assembling, organizing, innovating, conceptualizing, designing, and using different technologies; to draft, identify and evaluate complex challenges linking the two learning areas, using theories, tools, methods and knowledge To independently or collaboratively generate investigative, innovative or practical work to address the challenge; to complete summative projects, papers or technology applications based on current research, knowledge and technology.

2.1.2 Broad and integrated knowledge. Define, interpret and interpret a certain problem in science, art, society, human services, economic life or technology from at least two learning areas, and propose their own methods based on what they have learned; use the specific theories, tools and methods of at least two core learning areas to complete an investigative, creative or practical work; define and describe an important question in the main learning areas, which explains the significance of the challenge or problem in a broad social context, explains how to use the methods of major learning areas to solve the problems raised, and puts forward his own methods on the basis of cross domain.

\subsubsection{Intellectual skills}

2.1.3.1 Analysis and exploration. To identify and evaluate theories and methods related to selected complexity problems in a particular field of learning and at least one other field; master's degree. In the process of writing a thesis or implementing a project, deconstruct, reconstruct and adapt the main ideas, technologies or methods in the field of learning.

2.1.3.2 The use of information resources. To find, evaluate, integrate and appropriately refer to a variety of information resources from different media or languages to create projects, write papers or conduct presentations, generate information through independent or cooperative surveys, and use the information in projects, papers or presentations; master's degree. Provide evidence through papers, projects, notes, computer files or directories that can supplement, expand, evaluate, or improve the information base in the field of learning.

2.1.3.3 Diversified thinking. Create project books, experimental reports, exhibitions, demonstrations, or community service projects that reflect different cultural, political, or technical perspectives, and explain how this perspective differs from current reality. To express an argument or problem in the field of learning from at least two political, cultural, historical, or technical (power) perspectives, and to study and evaluate conflicting views on the debate or issue. On the premise of comprehensive consideration of various viewpoints, this paper makes oral or written rational analysis on the issue.

2.1.3.4 Ethical speculation. By analyzing the conflicting claims about the advantages and disadvantages of a recent discovery, scientific debate or technological practice, we can clearly explain the ethical dilemma contained in the contradiction between advantages and disadvantages, and can reconcile the contradiction between advantages and disadvantages under the guidance of ethical principles, or explain why the two cannot be reconciled. Identify and describe in detail the key ethical issues existing in at least one prominent social or cultural issue, explain at least the ways in which two different ethical perspectives affect decisions related to these issues, propose solutions to this ethical problem, and demonstrate its rationality.

2.1.3.5 Quantitative analysis. It uses mathematical algorithms to explain the practical problems described by language, uses the recognized mathematical reasoning symbol system for effective demonstration, and presents the final calculation, estimation, risk analysis or quantitative assessment of public information in papers, projects and multimedia demonstrations, and constructs appropriate mathematical expressions to interpret the problems originally described by non-quantitative terms. 
2.1.3.6 Smooth communication. For the public and professional groups, through written form and at least one other medium, to demonstrate, narrate or explain events, problems, technical matters and handling process continuously and consistently. In the field of learning that uses a large number of non-native language sources, conduct research on information, conditions, technology or practice, consult with one or more partners, present oral arguments, or elaborate a solution to social, personal, or moral dilemmas

2.1.4 Application and collaborative learning. Prepare and present projects, papers, exhibits, demonstrations or other appropriate forms of works, link the knowledge and skills acquired in work, community or research activities with the knowledge acquired in one or more fields, explain the composition of the work, and prove the relationship between the work and the literature in the field through appropriate citation; formulate team research or exhibition strategies through discussion, and record the following information To understand and implement the strategy and explain the results; to write a design, review or application description for a case or analysis scheme in the field of science, technology, economy, commerce, health, education or communication; to complete a project with practical significance and to evaluate an important problem in the field of students' learning, including an analytical description of the implementation process of extracurricular learning to the project The impact of research or practical skills used in.

2.1.5 Citizen and global learning. Explain people's multiple positions on a controversial public issue, including those representing different cultural, economic and regional interests, and evaluate the issue based on interests, evidence from the press and academia; put forward one's own position on a public issue and explain the reasons, and associate the position with other views in the public or policy environment; cooperate with others Develop and implement specific methods to solve a citizen's problem, evaluate the merits and demerits of the process, and describe the results in the applicable fields; identify an important issue affecting the country, mainland or culture, and present quantitative evidence on the problem through tables and charts; and evaluate the activities launched by NGOs or intergovernmental cooperation initiatives to solve the problem.

\subsection{DQP level interpretation}

DQP indicates that degree holders should better improve their "levels" in their professional fields. DQP separately describes the level that students should achieve in each field and integrates knowledge, intellectual skills, and some forms of achievement proof. Students learn through practice, and the level of each academic level is continuously accumulated. Therefore, the associate degree level is included in the bachelor's degree ability, which is reflected in the first two years of the four-year program, and the master's degree learning results also include the learning results of the associate degree and the bachelor's degree. Each part of DQP embodies the knowledge value-added and accumulated results from the low stage to the high stage. Students can acquire abilities and improve their level through various paths in the academic path. Learning proof materials are also cumulative ${ }^{[4]}$, and there are program differences and individual differences. These levels are shown through diagrams, papers, oral presentations or projects. The DQP system is designed to build a platform with a common framework for the evaluation and improvement of the quality of higher education at the national level. The American DQP degree qualification framework can provide a good reference for the construction of a modern vocational education system in China.

\section{Research on the teaching reform of pharmacology course aiming at ability training under the framework of American DQP degree qualification}

In the teaching of medicine and nursing majors in higher vocational colleges, pharmacology is a key content, which involves knowledge of various disciplines such as physiology, anatomy, pathophysiology, biochemistry, etc. The most important thing is to carry out pharmacology teaching with the organic and systematic integration that will help students lay a good foundation and facilitate the smooth development of follow-up teaching activities ${ }^{[5]}$.

The author draws on the American DQP degree qualification framework to carry out in-depth teaching reform research on the requirements of pharmacology curriculum ability training for medical and nursing majors in higher vocational colleges, and achieved good results.

\section{1 develop the pharmacology curriculum specification with competency training as the goal under the DQP degree qualification framework of the United States}

In 2014, according to DQP associate degree standard, our university established a unified framework for talent cultivation of various major categories, determined five major learning fields of students, and provided reference frame and benchmark for curriculum development and construction and credit setting of each specialty ${ }^{[6]}$. The credit value distribution of "Pharmacology" in the five major learning fields is shown in Figure 1. 


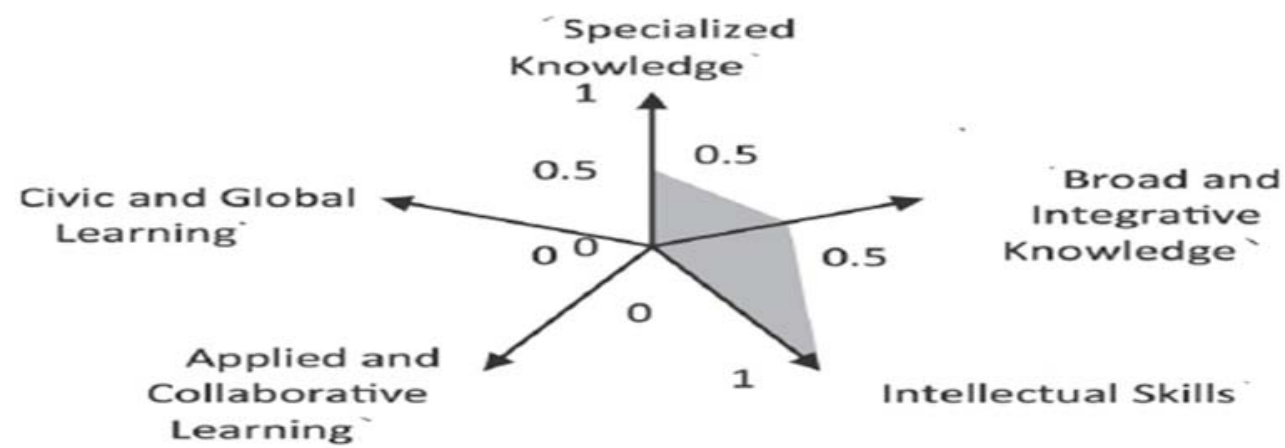

Figure 1 Distribution of credit value in five learning fields

At the first class of pharmacology course, our teachers will explain the pharmacology curriculum specification to the students, and then teach according to it. Meanwhile, we require the students to carry out self-study after class according to the requirements of the curriculum specification, so as to improve their ability ${ }^{[7]}$ and obtain the "expected learning results" in the corresponding fields based on the "Pharmacology" course in the five major learning fields ( Program outcome (POC) and corresponding credit value.Since September 2014, we have been adopting the DQP system to carry out pharmacology teaching and strictly follow the pharmacology curriculum standards. Through the questionnaire survey and analysis of the students, the questionnaire star survey shows that more than $89 \%$ of the students believe that the implementation of the DQP "pharmacology" curriculum standard will help students complete the homework inside and outside the classroom, and clarify the learning objectives and key difficulties of the course. Examinations also have a greater guiding role. At the same time, the implementation of curriculum standards allows students to clarify the functional positioning of "pharmacology" courses in professional learning and the relationship with professional capabilities. Students can build themselves, learn actively and complete related studies Achievements, exercise professional-related abilities, thereby further enhancing students' learning motivation and interest. See Chart 2 for details.

Since September 2014, we have been using DQP system to carry out pharmacology teaching in strict accordance with the pharmacology curriculum standards. The questionnaire survey of students shows that more than $89 \%$ of the students think that DQP based "Pharmacology" curriculum specification is helpful to complete the homework inside and outside the classroom, clarify the learning objectives and difficulties of the course, and have a greater guiding role in the examination. At the same time, the implementation of the curriculum specification can make students clear the functional orientation of "pharmacology" course learning in professional learning and the relationship between professional ability and students' self-construction and initiative Study and complete the relevant learning results, exercise the occupation related ability, so as to further enhance the students' learning motivation and interest. See Table 1 for details.

Table1 Students' recognition of DQP based "Pharmacology" curriculum specification

\begin{tabular}{l|r|r|}
\hline 1 The number of students who support DQP system in pharmacology teaching reform & 980 Proportion & $98 \%$ \\
2 The number of general supporters & 15 Proportion & $1.50 \%$ \\
\hline 3 The number of indifferent people & 2 Proportion & $0.20 \%$ \\
\hline 4 The number of objectors & 3 Proportion & $0.30 \%$ \\
\hline
\end{tabular}

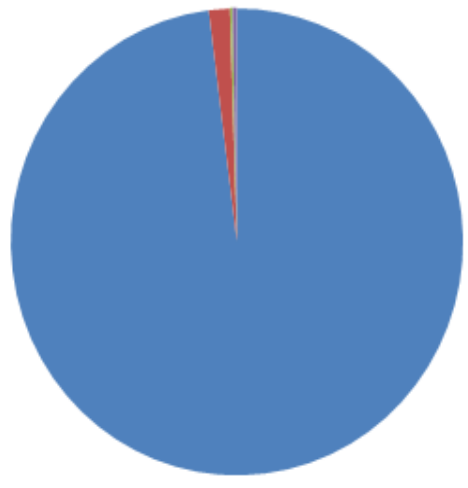

\subsection{Compile and select the latest pharmacology teaching materials that suitable for the actual work}

In terms of teaching content, considering that the knowledge of old textbooks is outdated and do not meet the current industry vocational skills requirements, we organize a team to compile new textbooks. The self-written textbook compilation team used is composed of teachers from many universities and vocational colleges, and medical doctors from hospitals. Specially 
we invited Professor Peilin Zheng of Shenzhen People's Hospital (Southern University of Science and Technology Affiliated Hospital), deputy chief physician Hong Xia of Guangzhou Panyu District Central Hospital, pharmacist Xingshan Kong of Guangzhou Medical University Second Affiliated Hospital to draw, and Professor Pinghua Sun of school of pharmacy of Jinan University, and Professor Haibo Zhou of school of pharmacy of Jinan University to review the textbook, which ensure it covering the most cutting-edge pharmacology knowledge. The characteristics are as follows:

(1) Appropriate content and distinctive features. The pharmacology textbook highlights the characteristics of higher vocational and technical education. It is compiled with "three basics (basic theory, basic knowledge, basic skills), five characteristics (ideological, scientific, enlightening, optimal, and practical)". We pay attention to the reform and innovation of teaching materials content, optimize the overall, and grasp the connection of depth, breadth, and content.

(2) Multidimensional writing style. The textbook focuses on cultivating students' vocational ability. We firstly clarify the learning objectives, and then use clinical cases to inspire students' interest in learning, and cultivate students' ability to link theory with practice; secondly, we insert knowledge links in the main text to highlight the key points, distinguish the priorities, expand students' horizons and inspire students' thinking. The end of each chapter is accompanied by a mind map, which cultivates students' holistic view and systematic learning thinking. In the end, each chapter adds a quiz for the nursing exam, which is convenient for students to review and self-test.

(3) To meet the needs of nursing examination. The content of the teaching materials is selected to meet the needs of nursing posts, professional standards and requirements. To facilitate the nurse qualification examination, we expanded the content on the preparation, usage and dosage, interaction of drugs.

(4) Book-network convergence. By scanning the two-dimensional code of the corresponding parts of each chapter of the paper-based teaching material, PPT courseware, micro lesson and other resources can be obtained to help students learn independently and fragmented.

In the teaching of using the new teaching material, students reflect that the new teaching material is more suitable for learning and practicing.

\subsection{The use of various teaching methods to achieve good teaching results}

The nursing students in our school come from the college entrance examination and classified enrollment examination. They don't have solid basic knowledge, high learning initiative, are afraid of difficulties and lack of interest in learning. The effect of traditional teaching methods is poor. After discussion, the pharmacology teaching and research group decided to carry out the teaching reform of pharmacology from September 2014: to improve teaching methods, update teaching tools, and pay attention to experimental exercises ${ }^{[8]}$, which did improve the teaching effects.

\subsubsection{Combining theory with practice to improve} teaching effect. The theoretical knowledge of pharmacology is linked with clinical nursing practice. By setting up multiple clinical nursing scenarios, students can be immersive in the face of patients in nursing positions. In the new teaching mode, the system of knowledge is improved, and the teaching content is divided into different sections according to the human organs. Take the teaching of cardiovascular system nursing medicine as an example. Before the teaching starts, students are introduced the structure of blood vessels and the heart, and then with the function of heart, the conditions required for normal heart function, the adjustment methods of the cardiovascular system, etc., and last the common diseases of the cardiovascular system, such as high blood pressure, angina, heart failure, shock, etc. After the above content is explained, students will be taught with prevention and treatment of cardiovascular disease, and the rational use of drugs. Such a teaching mode is very consistent with the students' cognitive law and effectively improves the practicality and rationality of the course content. It can also avoid the repetition of teaching content and the disconnection of teaching time, save time and effort, effectively improve students' enthusiasm for learning, and achieve the purpose of teaching.

\subsubsection{Focusing on the integration of pharmacological} experiments. Pharmacology is a highly practical course, which requires students' innovation ability. However, the teaching hours of pharmacology are limited. In order to achieve the teaching effect of learning for application and meet the needs of nursing posts of vocational college students, it is necessary to reduce the explanation in class, increase the training content, select some theoretical knowledge to be interposed into the training content, which can not only help students master more theoretical knowledge, but also exercise students' practical ability and innovation ability, and mobilize students' learning enthusiasm. In view of this, under the new teaching mode, the pharmacology teaching content needs to be adjusted and supplemented reasonably. We have added the designed experiment and comprehensive experiment by using self-made drama in the new textbook.

Nursing pharmacology is a compulsory professional basic course for nursing majors. But for a long time, the main content of pharmacology experimental teaching is mostly confirmatory experiments to verify the theory of drug action. In traditional pharmacology experimental teaching, a parallel teaching model of theory and practice is adopted, which contains basic experiments, design experiments and comprehensive experiments. In the teaching mode based on the integration of biological systems, the teaching focuses on the training of student skills, organically integrating pathophysiology, physiology and pharmacology experimental courses into 
a new system ${ }^{[9]}$. After integration, the experimental courses are more independent, more practical, and can better meet the needs of nursing posts. It can also greatly reduce the content of basic experiments and demonstrative experiments, and add comprehensive experiments and design experiments. In addition, the school has also taken reasonable measures to improve the laboratory environment. The basic experimental operations are mainly explained by teachers, and the students will be taught and demonstrated experimental theories and operations. After that, students will finish design experiments by themselves in the laboratory. This can not only improve students' ability to analyze problems, but also cultivate their innovative abilities and future development.

In response to the needs of nursing professional positions, the pharmacology teaching and research group reformed the experimental content, selecting some experiments that are closely related to theoretical teaching, easy to operate, such as the "Organic Phosphate Poisoning and Rescue" experiment. In the experiment, the students remembered M-like symptoms and N-like symptoms by observing the symptoms before and after poisoning in rabbits. After the injections of atropine and pralidoxime chloride, the different symptoms of poisoning in rabbits were improved, which deepened students' understanding and memory of the content of theoretical lessons. In addition, the pharmacology teaching and research group simplifies and optimizes the experimental content. For example, the experiment of "Injection Compounding and Drug Compatibility" requires $0.1 \mathrm{~g}$ of erythromycin injection powder, which is difficult in actual operation. Therefore, the pharmacology teaching and research group carried out the experimental plan. Optimization, inject water for injection, $0.9 \%$ injection, and 5\% glucose injection directly into the packaging bottles of erythromycin powder for injection numbered 1, 2, and 3, and observe the dissolution of erythromycin in different solvents For sex, knight students master how to choose the solvent correctly.

Higher vocational nursing pharmacology experiment plays an important role in the basic medical experiment. The reform, innovation and development of pharmacological experiment teaching need to be further studied and improved to find more appropriate teaching $\operatorname{methods}^{[10]}$.

\subsubsection{Combine the majority oriented teaching with individualized teaching and organize the teaching} content reasonably. In teaching, we should not only face the majority of students, but also proceed from the actual situation of the students, recognize individual differences, and pay attention to the students who are unable to do well. The design of teaching content should conform to the cognitive laws of students, the psychological process of learning, the level of students and teaching needs. This is an important aspect of "teaching in accordance with their aptitude" or "preparing for study" in preparing lessons. We organize and arrange teaching content in a reasonable manner based on the characteristics of students. Vocational college students have no clinical experience, strong memory, and poor understanding. Therefore, the teaching process should not involve too much coverage. The key content should be breakthrough little by little, and each knowledge point should be concise and easy to understand. The content is overlapped, so that the knowledge is clear and lively, but also to avoid the occurrence of interference that affects learning interest. The teaching content meets the needs of most students in depth and breadth. For students who are able to learn, some new knowledge and new progress are arranged in the teaching; for students who are unable to do so, the key and difficult parts are explained in detail.

\subsubsection{Use induction method to improve students' memory efficiency of knowledge. The teaching content} in each nursing situation can be summarized as Formulas that easy to understand and remember. For example, the antibacterial mechanism of antimicrobials can be summarized as follows: the antibacterial mechanism is easy to distinguish, and the cell wall of Penicillium plays a leading role; polyviscous double injection membrane permeation, sulfamethoxazole nucleic acid is poor; red, new, card, chlorine, chain, Qing, four, prevent protein synthesis. Another example is the main pharmacological action of cardiac glycoside, which is not only the key but also the difficulty. It is summarized into two pithy formulas: strong contraction and slow jump, decrease oxygen consumption, slow conduction and diuresis. Through the study of pithy formula, the memory of pharmacology knowledge becomes regular, methodical and interesting. The students like it very much and the effect is very good.

3.3.5 Emphasis on difficulties and key points. For difficulties and key points in each chapter, we speak clearly and thoroughly to make it clear for students. For example, when teaching angiotensin-converting enzyme inhibitors, captopril should be taken as the key drug to introduce the function and suitability of captopril in detail. As for other drugs, the differences can be highlighted through comparison.

3.3.6 Questioning method. We create problem situations, guide and inspire students' independent thinking. For example, when teaching inefficient diuretics, in order to distinguish the effects of spironolactone and aminophenytoin, it was proposed that "after adrenalectomy, what are the diuretic effects of the two drugs?" Questions. Each student was very interested in thinking and exchanging their own ideas. They took questions to listen to the teacher's lecture on the diuretic mechanism of spironolactone and aminophenanthroline. It was natural for them to get the answers to the above questions according to the mechanism of the two drugs. All the students could analyze and get the correct answer: "spironolactone loses its diuretic effect, but the diuretic effect of aminophenanthroline remains unchanged". Later, when it comes to low efficiency diuretics, students can clearly remember the effect of low efficiency diuretics 
when they think of the teacher's question.

\subsubsection{Crisscross teaching method. After introducing} the structure and characteristics of each drug in a longitudinal manner, the students' knowledge will be crossed so as to enhance the integrity and comprehensiveness of their knowledge. For example, after longitudinal introduction of $\mathrm{M}$ receptor blockers, central analgesics and antipyretic analgesics, the analgesic effects of atropine, morphine and aspirin can be compared, and their analgesic mechanisms and indications can be explained respectively ${ }^{[11]}$. Through the use of a variety of teaching methods, students in the classroom thinking more active, not easy to lead to learning fatigue, so as to improve the effect of classroom teaching.

3.3.8 Flipped classroom method. Before class, teachers integrate and upload the learning materials such as teaching video and micro class to the online learning platform, and release the preview notice through Wechat group and QQ email. After receiving the preview notice, students download the network electronic files, micro courses, teaching videos and other information-based teaching resources for autonomous learning. The implementation of the teaching method expands and extends the learning time and space outside the classroom.

3.3.9 Task driven teaching method. Teachers use video case introduction, create situations, assign tasks, discuss and practice with teachers and students.

\subsubsection{Group cooperation inquiry teaching method.}

They are divided into 8 groups with 6-7 people in each group. They learn the complicated contents of the course by making plans, inquiring about materials, discussing and researching, making PPT in groups, and then reporting in groups.

\subsubsection{Group discussion teaching method. Teachers} put forward some key and difficult questions, organized students to discuss to better achieve the teaching objectives. Through the above activities, students have acquired knowledge and skills and rich emotional experience, which not only improves the team awareness of the group members, but also promotes the students to develop their strengths and avoid weaknesses, and make common progress. It can also cultivate their self-learning ability, speculative ability, activity organization ability, and complete the expected results of the curriculum specification.

\subsubsection{Introducing the medical story to arouse} students' interest. Classroom atmosphere is dull in the traditional pharmacology teaching. A good introduction of new medical story can improve students' interest. For example, when explaining penicillin, first play the video "discovery of penicillin", so that students can understand the historical background of the emergence of penicillin and the historical position of penicillin in the history of medicine. At the end of the video, according to the important and difficult contents of this lesson, the teacher asked three questions in time: (1) can penicillin treat all microbial infections? (2) why can penicillin save the lives of soldiers? (3) is penicillin still used in clinic? (major adverse reactions). With these problems to learn, arouse the curiosity of students, impressed.

3.3.13 Heuristic teaching method to cultivate students' habit of thinking. Pharmacology is not only closely associated with clinical practice, but also closely related to daily life. In the process of pharmacology teaching, heuristic teaching is used to introduce book knowledge from common plants and animals in daily life to cultivate students' habit of thinking. For example, when explaining antipyretic analgesics, the poem "chanting willows" was introduced first: Jasper was made up of a tree height, and thousands of green silk tapestries hung down. I don't know who cut the thin leaves. The spring breeze in February is like scissors. Then he asked, the poet he Zhizhang saw the willows everywhere and wrote a famous sentence for thousands of years. As a medical student, have you ever thought about whether willows can cure diseases? Then it leads to the ancient medical records of willow bark in the treatment of fever, pain and rheumatoid arthritis, as well as the question of scientists: what magical substances can cure diseases in willow bark? With the development of science, scientists extracted salicylic acid from willow bark and synthesized it into a drug development history of aspirin. Because of the continuous thinking of human beings, it promotes the development of human medicine.

\subsubsection{Case teaching method to stimulate learning} enthusiasm. Pharmacology is closely combined with clinical practice. According to the needs of nursing posts, classic cases are selected from clinical cases, and appropriate teaching organization forms are adopted for teaching to stimulate students' learning enthusiasm. For example, when explaining anti Parkinson drugs, first play a video of the clinical symptoms of Parkinson's patients, introduce clinical cases with words, and then ask "why do these patients have Parkinson's symptoms?" This paper introduces the pathogenesis of Parkinson's disease, and then asks "what drugs are used to treat Parkinson's disease?"? What is the effect? " The mechanism of action of anti Parkinson's disease drugs and the content of adverse reactions were introduced. The video is intuitive and novel, which gives students a visual impact, improves the previous rigid classroom atmosphere, and improves the boring characteristics of pharmacology content. With heuristic questions, curiosity is aroused, teachers explain in detail and solve doubts. Students experience the pleasure of learning, which significantly improves the effect of classroom teaching. 
3.3.15 Rhyme memorizing method to solve difficult memory. Pharmacology has many contents that difficult to remember. In the teaching process, the homophonic and rhyme forms are used to make the memory content short and concise, catchy, and reduce the difficulty of students' memory. For example, the adverse reaction of aspirin is "Yi (pancreas) Wei (stomach) you (coagulation) Yang (salicylic acid) Ming (Allergic reaction)". The adverse reactions of hydrochlorothiazide are "one low and three high" (hypokalemia, hyperglycemia, hyperlipidemia and hyperuricemia). The antibacterial spectrum of penicillin is "three bacteria in one and one actinomycetes, Yang is prosperous and Yin is declining" (gram-positive cocci, Gram-positive bacilli, gram-negative cocci, spirochetes and actinomycetes). The prevention and treatment measures of penicillin anaphylactic shock are "one question, two trials, three observations, four injections and five rescue".

3.3.16 Situational teaching method to cultivate comprehensive ability. For common clinical diseases or symptoms, such as fever, pain, cough, cold, etc., scene teaching was carried out in the simulated pharmacy of the school. First of all, the whole class is divided into groups. Then, one of the students in the group plays the role of patient (set up different patients, such as children, adults, the elderly, pregnant women, patients with allergic history), and the other plays the role of pharmacist. "Pharmacists" recommend appropriate drugs according to the symptoms stated by "patients", and instruct medication precautions. For special patients, they can make correct medication guidance according to the patient's situation. The situational teaching method, through role play, not only stimulates students' learning enthusiasm, but also directly faces "patients", enhances students' ability of rational drug use and combined medication, and strengthens students' sense of responsibility.

\subsection{Full use of modern technology to assist experimental and theoretical teaching}

\subsubsection{The use of multimedia for theory teaching.}

With the rapid development of modern science and technology, the introduction of modern teaching methods is imperative. Compared with the traditional teaching, it is more conducive to students' understanding of abstract and conceptual content, stimulating students' interest in learning, enhancing students' memory and understanding of knowledge, and using animation to express complex and abstract mechanism of drug action. On the premise of ensuring scientific nature, artistic quality can be realized as much as possible. With the development of science and technology, there are more and more new drugs. At the same time, with the extensive application and in-depth study of some drugs, new effects and adverse reactions of drugs are gradually found. Therefore, the teaching content must be based on the combination of clinical and theoretical experiments, which can reflect the frontier knowledge and research trend, broaden the students' vision, and increase the amount of knowledge under the condition of unchanged class hours.

\subsubsection{Multimedia in pharmacology experiment} teaching. Multimedia can enrich the content of experimental class. Multimedia can spread a large amount of information in a short time, enriching the experimental content. We need to raise funds from various sources to build a high standard laboratory. For example, the Medlab biological signal acquisition and processing system was used in the experiment of "the rescue of respiratory depression caused by morphine by nicothamide". The traditional dual channel physiological recorder was replaced by computer and software, which not only improved the accuracy of the experimental results, but also promoted people to use advanced means in scientific experiments With the understanding, stimulate students' interest in learning and exploring pharmacological knowledge, and cultivate students' spirit of knowledge exploration and innovation. The application of modern education technology optimizes the teaching process, improves the quality of teaching and meets the needs of innovative and skilled personnel training.

\subsubsection{Micro class, MOOC, and sharing teaching} resources. Due to the characteristics of pharmacology, the traditional teaching mode is boring, resulting in the not good teaching effect. In order to change this situation, the pharmacology teaching and research group adapts to the new era of "Internet +", while using a variety of teaching methods, combined with the information-based teaching forms of micro class and MOOC. Micro class is characterized by "short, small, refined and flexible" ${ }^{[12]}$. A video explaining a certain teaching point or a teaching link takes 5-10 minutes in general and 15 minutes at most. For example, the diuretic mechanism of diuretics, the addiction of narcotic analgesics, and the influence of aspirin and chlorpromazine on body temperature were used as subjects to make micro lecture to break through the key and difficult points in pharmacology teaching. The system and coherence of micro class are insufficient ${ }^{[13]}$, so MOOC emerges as the times require.

\subsection{Continuously improve teachers' quality in teaching reform}

As the saying goes, "the iron has to be hard itself", "to give students a bowl of water, the teacher should have a bucket of water". The key to improve the quality of teaching lies in teachers. Without a teacher with solid professional knowledge and excellent teaching level, it is difficult to improve the teaching quality. In today's society, with the rapid development of science and technology and the continuous updating of drugs, pharmacology teachers are required to constantly update their knowledge, grasp the industry trends, closely combine with clinical practice, and add the latest, more safe and effective drugs [14] to the teaching. In addition, the traditional pharmacology teaching method with 
teachers as the main body and blackboard writing as the main body can not meet the needs of students in the new era. Pharmacology teachers should constantly update their own teaching methods, update teaching tools and use multimedia teaching and information teaching methods to change the status quo. Therefore, the author's college holds information-based teaching competition every year to promote teachers to update teaching methods. It is not enough for teachers to develop themselves by themselves. They need teamwork and common learning. Young teachers need experienced teachers to "pass on, help and lead"; young teachers can help old teachers update teaching tools. Pharmacology teaching and research group members learn from each other ${ }^{[15]}$, and make common progress.

\subsection{Reform the evaluation method of teaching achievements}

The traditional teaching evaluation is a "Teacher centered" teaching process evaluation. We need to reform the evaluation method of teaching achievements, and emphasize the student-centered in pharmacology teaching. Under the DQP framework, students are the main body of teaching. The evaluation of teaching achievements should be student-centered. In the evaluation of student-centered teaching achievements, it is important to solve the following problems: (1) what are the achievements we want students to achieve? (2) Does the student know how to achieve his goal? (3) How can a student know if he has achieved his goal [13]? However, due to the particularity of nursing specialty, students can not be completely laissez faire. Respect for life is the most important professional ethics in nurses' professional activities. Nursing students lack the reality of hospital work in school. Teachers should help students think about nursing profession from the perspective of life science and bioethics, internalize professional ethics and enhance professional responsibility ${ }^{[16]}$.

Besides the traditional examination materials, it also includes audio, video, documents, photos, activities, lectures, questionnaires, etc. To change the monotony of previous teaching results [17], students can show their learning achievements in surgical nursing learning process through various ways and means. The emphasis is on encouraging students to consult literature extensively and increase the width and depth of knowledge. Teaching achievement is not something that students recite, understand or memorize for a short time, but something that can be internalized into the heart of students. Teaching achievement is the final result obtained by students, which is the greatest ability that all students can achieve through their efforts.

\section{Teaching reform effect of Pharmacology Course}

Since September 2014, we have been carrying out research on pharmacology teaching reform under DQP system. We continue to deepen the reform, improve the teaching effect and students' ability. Before the Teaching Reform ${ }^{[18]}$, the average score of pharmacology course for students majoring in medicine and nursing was 73.94 \pm 10.60 . After the reform, the average score at the end of each semester was more than $88.72 \pm 5.28$, which was significantly improved. The students' basic mastery of pharmacology was $85.19 \%$, and the students' satisfaction with the course was $90.41 \%$ The scores are higher than the average excellent rate and course satisfaction rate of students at the end of the term before the implementation. The passing rate of students' examination has been significantly improved, and the learning initiative and enthusiasm have also been greatly improved.

Table 2 Pharmacology assessment in January 2020

\begin{tabular}{|c|c|c|c|c|c|c|c|c|c|c|}
\hline $\begin{array}{l}\text { Teaching } \\
\text { class }\end{array}$ & \multicolumn{2}{|c|}{ 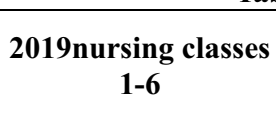 } & \multicolumn{2}{|c|}{ Total students } & \multicolumn{2}{|c|}{300} & \multicolumn{2}{|c|}{$\begin{array}{l}\text { Total expected } \\
\text { learning } \\
\text { outcomes }\end{array}$} & \multicolumn{2}{|c|}{4} \\
\hline No-Proportio & \multicolumn{2}{|c|}{$\geq 90$} & \multicolumn{2}{|c|}{$[80,90)$} & \multicolumn{2}{|c|}{$[60,80)$} & \multicolumn{2}{|c|}{$<60$} & \multicolumn{2}{|c|}{$\begin{array}{l}\text { Abnormal } \\
\text { assessment }\end{array}$} \\
\hline $\begin{array}{l}\text { Learning } \\
\text { outcomes }\end{array}$ & Numb-er & $\begin{array}{l}\text { Propo- } \\
\text { rtion }\end{array}$ & $\begin{array}{l}\text { Nu- } \\
\text { mber }\end{array}$ & $\begin{array}{l}\text { Propo } \\
\text {-rtion }\end{array}$ & $\begin{array}{l}\text { Nu- } \\
\text { mber }\end{array}$ & $\begin{array}{l}\text { Propo- } \\
\text { rtion }\end{array}$ & $\begin{array}{c}\text { Nu } \\
\text {-mber }\end{array}$ & $\begin{array}{l}\text { Propo } \\
\text {-rtion }\end{array}$ & $\begin{array}{c}\text { Num- } \\
\text { ber }\end{array}$ & $\begin{array}{l}\text { Propo- } \\
\text { rtion }\end{array}$ \\
\hline SOC1 & 38 & 16.3 & 95 & 40.4 & 99 & 42.1 & 3 & 1.2 & 0 & 0 \\
\hline SOC2 & 45 & 19.2 & 98 & 41.7 & 90 & 38.3 & 2 & 0.8 & 0 & 0 \\
\hline SOC3 & 52 & 22.1 & 105 & 44.7 & 77 & 32.8 & 1 & 0.4 & 0 & 0 \\
\hline SOC4 & 60 & 25.5 & 136 & 57.9 & 39 & 16.6 & 0 & 0 & 0 & 0 \\
\hline final exam & 60 & 25.5 & 136 & 57.9 & 39 & 16.6 & 0 & 0 & 0 & 0 \\
\hline $\begin{array}{c}\text { Course } \\
\text { comprehensive } \\
\text { score }\end{array}$ & 75 & 32 & 118 & 50 & 42 & 18 & 0 & 0 & 0 & 0 \\
\hline
\end{tabular}

Table 3 Pharmacology assessment in January 2019

\begin{tabular}{|l|c|c|c|c|c|}
\hline $\begin{array}{c}\text { Teaching } \\
\text { class }\end{array}$ & $\begin{array}{c}\text { 2018nursing } \\
\text { classes 1-6 }\end{array}$ & Total students & 300 & $\begin{array}{c}\text { Total expected } \\
\text { learning } \\
\text { outcomes }\end{array}$ & 4 \\
\hline
\end{tabular}




\begin{tabular}{|c|c|c|c|c|c|c|c|c|c|c|}
\hline \multirow{2}{*}{$\begin{array}{l}\text { Grade } \\
\text { NO-Proportion } \\
\text { Learning } \\
\text { outcomes }\end{array}$} & \multicolumn{2}{|c|}{$\geq 90$} & \multicolumn{2}{|c|}{$[80,90)$} & \multicolumn{2}{|c|}{$[60,80)$} & \multicolumn{2}{|c|}{$<60$} & \multicolumn{2}{|c|}{$\begin{array}{c}\text { Abnormal } \\
\text { assessment }\end{array}$} \\
\hline & $\begin{array}{l}\text { Numb } \\
\text {-er }\end{array}$ & $\begin{array}{c}\text { Propo- } \\
\text { rtion }\end{array}$ & $\begin{array}{l}\text { Num- } \\
\text { ber }\end{array}$ & $\begin{array}{c}\text { Propo- } \\
\text { rtion }\end{array}$ & $\begin{array}{c}\text { Numb- } \\
\text { er }\end{array}$ & $\begin{array}{c}\text { Propor- } \\
\text { tion }\end{array}$ & $\begin{array}{c}\text { Numb } \\
\text {-er }\end{array}$ & $\begin{array}{c}\text { Propo- } \\
\text { rtion }\end{array}$ & $\begin{array}{c}\text { Num } \\
\text {-ber }\end{array}$ & $\begin{array}{c}\text { Propo- } \\
\text { rtion }\end{array}$ \\
\hline SOC1 & 54 & 18 & 120 & 40 & 123 & 41 & 3 & 1 & 0 & 0 \\
\hline SOC2 & 57 & 19 & 123 & 41 & 114 & 38 & 6 & 2 & 0 & 0 \\
\hline SOC3 & 51 & 17 & 120 & 40 & 123 & 41 & 6 & 2 & 0 & 0 \\
\hline SOC4 & 90 & 30 & 90 & 30 & 114 & 38 & 6 & 2 & 0 & 0 \\
\hline final exam & 90 & 30 & 90 & 30 & 111 & 37 & 9 & 3 & 0 & 0 \\
\hline $\begin{array}{c}\text { Course } \\
\text { comprehensive } \\
\text { score }\end{array}$ & 90 & 30 & 144 & 50 & 87 & 29 & 0 & 0 & 0 & 0 \\
\hline
\end{tabular}

Table4 Pharmacology assessment in January 2018

\begin{tabular}{|c|c|c|c|c|c|c|c|c|c|c|}
\hline Teaching class & \multicolumn{2}{|c|}{$\begin{array}{l}\text { 2017nursing } \\
\text { classes } 1-6\end{array}$} & \multicolumn{2}{|c|}{ Total students } & \multicolumn{2}{|c|}{300} & \multicolumn{2}{|c|}{$\begin{array}{c}\text { Total expected } \\
\text { learning } \\
\text { outcomes } \\
\end{array}$} & \multicolumn{2}{|c|}{4} \\
\hline $\begin{array}{c}\text { Grade } \\
\text { NQ-Proportion }\end{array}$ & \multicolumn{2}{|c|}{$\geq 90$} & \multicolumn{2}{|c|}{$[80,90)$} & \multicolumn{2}{|c|}{$[60,80)$} & \multicolumn{2}{|c|}{$<60$} & \multicolumn{2}{|c|}{$\begin{array}{c}\text { Abnormal } \\
\text { assessment }\end{array}$} \\
\hline $\begin{array}{l}\text { Learning } \\
\text { outcomes }\end{array}$ & $\begin{array}{l}\text { Numb } \\
\text {-er }\end{array}$ & $\begin{array}{l}\text { Propo- } \\
\text { rtion }\end{array}$ & $\begin{array}{l}\text { Num- } \\
\text { ber }\end{array}$ & $\begin{array}{l}\text { Propo } \\
\text {-rtion }\end{array}$ & $\begin{array}{c}\text { Numb } \\
-e r\end{array}$ & $\begin{array}{l}\text { Propo } \\
\text {-rtion }\end{array}$ & $\begin{array}{c}\text { Numb- } \\
\text { er }\end{array}$ & $\begin{array}{c}\text { Propo- } \\
\text { rtion }\end{array}$ & $\begin{array}{c}\text { Numb } \\
\text {-er }\end{array}$ & $\begin{array}{c}\text { Propo- } \\
\text { rtion }\end{array}$ \\
\hline $\mathrm{SOC1}$ & 60 & 20 & 120 & 40 & 99 & 36 & 12 & 4 & 0 & 0 \\
\hline SOC2 & 63 & 21 & 120 & 40 & 99 & 36 & 9 & 3 & 0 & 0 \\
\hline SOC3 & 66 & 22 & 126 & 42 & 102 & 34 & 6 & 2 & 0 & 0 \\
\hline SOC4 & 60 & 20 & 126 & 42 & 102 & 34 & 12 & 4 & 0 & 0 \\
\hline final exam & 75 & 25 & 105 & 35 & 99 & 36 & 12 & 4 & 0 & 0 \\
\hline $\begin{array}{c}\text { Course } \\
\text { comprehensive } \\
\text { score }\end{array}$ & 84 & 28 & 114 & 43 & 90 & 30 & 0 & 0 & 0 & 0 \\
\hline
\end{tabular}

Table5 Pharmacology assessment in January 2017

\begin{tabular}{|c|c|c|c|c|c|c|c|c|c|c|}
\hline $\begin{array}{l}\text { Teaching } \\
\text { class }\end{array}$ & \multicolumn{2}{|c|}{$\begin{array}{l}\text { 2016nursing } \\
\text { classes } 1-6\end{array}$} & \multicolumn{2}{|c|}{ Total students } & \multicolumn{2}{|c|}{300} & \multicolumn{2}{|c|}{$\begin{array}{c}\text { Total expected } \\
\text { learning } \\
\text { outcomes }\end{array}$} & \multicolumn{2}{|c|}{4} \\
\hline Grade & \multicolumn{2}{|c|}{$\geq 90$} & \multicolumn{2}{|c|}{$[80,90)$} & \multicolumn{2}{|c|}{$[60,80)$} & \multicolumn{2}{|c|}{$<60$} & \multicolumn{2}{|c|}{$\begin{array}{l}\text { Abnormal } \\
\text { assessment }\end{array}$} \\
\hline $\begin{array}{l}\text { Learning } \\
\text { outcomes }\end{array}$ & $\begin{array}{l}\text { Numb- } \\
\text { er }\end{array}$ & $\begin{array}{l}\text { Prop- } \\
\text { ortion }\end{array}$ & $\begin{array}{l}\text { Numb- } \\
\text { er }\end{array}$ & $\begin{array}{c}\text { Propo- } \\
\text { rtion }\end{array}$ & $\begin{array}{c}\text { Numb } \\
-e r\end{array}$ & $\begin{array}{c}\text { Propo- } \\
\text { rtion }\end{array}$ & $\begin{array}{c}\text { Numb- } \\
\text { er }\end{array}$ & $\begin{array}{c}\text { Propo- } \\
\text { rtion }\end{array}$ & $\begin{array}{c}\text { Numb- } \\
\text { er }\end{array}$ & $\begin{array}{c}\text { Propo- } \\
\text { rtion }\end{array}$ \\
\hline SOC1 & 75 & 25 & 105 & 35 & 99 & 36 & 12 & 4 & 0 & 0 \\
\hline SOC2 & 60 & 20 & 120 & 40 & 99 & 36 & 12 & 4 & 0 & 0 \\
\hline SOC3 & 63 & 21 & 120 & 40 & 99 & 36 & 9 & 3 & 0 & 0 \\
\hline SOC4 & 66 & 22 & 126 & 42 & 102 & 34 & 6 & 2 & 0 & 0 \\
\hline final exam & 60 & 20 & 126 & 42 & 102 & 34 & 12 & 4 & 0 & 0 \\
\hline $\begin{array}{c}\text { Course } \\
\text { comprehensive } \\
\text { score }\end{array}$ & 72 & 24 & 126 & 42 & 102 & 34 & 0 & 0 & 0 & 0 \\
\hline
\end{tabular}

Table 6 Pharmacology assessment in January 2016

\begin{tabular}{|l|c|c|c|c|c|}
\hline Teaching class & $\begin{array}{c}\text { 2015nursing } \\
\text { classes 1-6 }\end{array}$ & Total students & 300 & $\begin{array}{c}\text { Total } \\
\text { expected } \\
\text { learning } \\
\text { outcomes }\end{array}$ & 4 \\
\hline
\end{tabular}




\begin{tabular}{|c|c|c|c|c|c|c|c|c|c|c|}
\hline \multirow{2}{*}{$\begin{array}{l}\text { Grade } \\
\text { NQ-Proportion } \\
\text { Learning } \\
\text { outcomes }\end{array}$} & \multicolumn{2}{|c|}{$\geq 90$} & \multicolumn{2}{|c|}{$[80,90)$} & \multicolumn{2}{|c|}{$[60,80)$} & \multicolumn{2}{|c|}{$<60$} & \multicolumn{2}{|c|}{$\begin{array}{c}\text { Abnormal } \\
\text { assessment }\end{array}$} \\
\hline & $\begin{array}{l}\text { Numb- } \\
\text { er }\end{array}$ & $\begin{array}{l}\text { Prop- } \\
\text { ortion }\end{array}$ & $\begin{array}{l}\text { Numb } \\
\text {-er }\end{array}$ & $\begin{array}{l}\text { Propo } \\
\text {-rtion }\end{array}$ & $\begin{array}{c}\text { Numb } \\
\text {-er }\end{array}$ & $\begin{array}{c}\text { Propo- } \\
\text { rtion }\end{array}$ & $\begin{array}{l}\text { Num } \\
\text { b-er }\end{array}$ & $\begin{array}{l}\text { Propo } \\
\text {-rtion }\end{array}$ & $\begin{array}{c}\text { Numb } \\
\text {-er }\end{array}$ & $\begin{array}{l}\text { Propo } \\
\text {-rtion }\end{array}$ \\
\hline SOC1 & 63 & 21 & 120 & 40 & 99 & 36 & 9 & 3 & 0 & 0 \\
\hline SOC2 & 66 & 22 & 126 & 42 & 102 & 34 & 6 & 2 & 0 & 0 \\
\hline SOC3 & 60 & 20 & 126 & 42 & 102 & 34 & 12 & 4 & 0 & 0 \\
\hline SOC4 & 72 & 24 & 126 & 42 & 96 & 32 & 6 & 2 & 0 & 0 \\
\hline final exam & 75 & 25 & 126 & 42 & 99 & 33 & 0 & 0 & 0 & 0 \\
\hline $\begin{array}{c}\text { Course } \\
\text { comprehensive } \\
\text { score }\end{array}$ & 72 & 24 & 126 & 42 & 102 & 34 & $\mathbf{0}$ & 0 & 0 & 0 \\
\hline
\end{tabular}

Table 7 Pharmacology assessment in January 2015

\begin{tabular}{|c|c|c|c|c|c|c|c|c|c|c|}
\hline $\begin{array}{l}\text { Teaching } \\
\text { class }\end{array}$ & \multicolumn{2}{|c|}{$\begin{array}{c}\text { 2014nursing } \\
\text { classes 1-6 }\end{array}$} & \multicolumn{2}{|c|}{ Total students } & \multicolumn{2}{|c|}{300} & \multicolumn{2}{|c|}{$\begin{array}{l}\text { Total expected } \\
\text { learning } \\
\text { outcomes }\end{array}$} & \multicolumn{2}{|c|}{4} \\
\hline $\begin{array}{c}\text { Grade } \\
\text { NQ-Proportion }\end{array}$ & \multicolumn{2}{|c|}{$\geq 90$} & \multicolumn{2}{|c|}{$[80,90)$} & \multicolumn{2}{|c|}{$[60,80)$} & \multicolumn{2}{|c|}{$<60$} & \multicolumn{2}{|c|}{$\begin{array}{c}\text { Abnormal } \\
\text { assessment }\end{array}$} \\
\hline $\begin{array}{l}\text { Learning } \\
\text { outcomes }\end{array}$ & $\begin{array}{l}\text { Numb } \\
\text {-er }\end{array}$ & $\begin{array}{c}\text { Propo- } \\
\text { rtion }\end{array}$ & $\begin{array}{l}\text { Numb } \\
\text {-er }\end{array}$ & $\begin{array}{l}\text { Propo } \\
\text {-rtion }\end{array}$ & $\begin{array}{c}\text { Numb } \\
\text {-er }\end{array}$ & $\begin{array}{c}\text { Propo- } \\
\text { rtion }\end{array}$ & $\begin{array}{c}\text { Numb } \\
\text {-er }\end{array}$ & $\begin{array}{l}\text { Propo } \\
\text {-rtion }\end{array}$ & $\begin{array}{c}\text { Numb } \\
\text {-er }\end{array}$ & $\begin{array}{c}\text { Propo- } \\
\text { rtion }\end{array}$ \\
\hline SOC1 & 72 & 24 & 126 & 42 & 99 & 33 & 3 & 1 & 0 & 0 \\
\hline SOC2 & 63 & 21 & 120 & 40 & 99 & 36 & 9 & 3 & 0 & 0 \\
\hline SOC3 & 66 & 22 & 126 & 42 & 102 & 34 & 6 & 2 & 0 & 0 \\
\hline SOC4 & 60 & 20 & 126 & 42 & 102 & 34 & 12 & 4 & 0 & 0 \\
\hline final exam & 72 & 24 & 126 & 42 & 96 & 32 & 6 & 2 & 0 & 0 \\
\hline $\begin{array}{c}\text { Course } \\
\text { comprehensive } \\
\text { score } \\
\end{array}$ & 75 & 25 & 126 & 42 & 99 & 33 & 0 & 0 & 0 & 0 \\
\hline
\end{tabular}

Table 8 Pharmacology assessment in January 2014

\begin{tabular}{|c|c|c|c|c|c|c|c|c|c|c|}
\hline \multirow{3}{*}{$\begin{array}{l}\begin{array}{c}\text { Teaching } \\
\text { class }\end{array} \\
\begin{array}{c}\text { Grade } \\
\text { NQ-Proportion }\end{array} \\
\begin{array}{l}\text { Learning } \\
\text { outcomes }\end{array}\end{array}$} & \multicolumn{2}{|c|}{$\begin{array}{l}2013 \text { nursing } \\
\text { classes 1-6 }\end{array}$} & \multicolumn{2}{|c|}{ Total students } & \multicolumn{2}{|c|}{300} & \multicolumn{2}{|c|}{$\begin{array}{l}\text { Total expected } \\
\text { learning } \\
\text { outcomes }\end{array}$} & \multicolumn{2}{|c|}{4} \\
\hline & \multicolumn{2}{|c|}{$\geq 90$} & \multicolumn{2}{|c|}{$[80,90)$} & \multicolumn{2}{|c|}{$[60,80)$} & \multicolumn{2}{|c|}{$<60$} & \multicolumn{2}{|c|}{$\begin{array}{c}\text { Abnormal } \\
\text { assessment }\end{array}$} \\
\hline & $\begin{array}{l}\text { Num } \\
\text {-ber }\end{array}$ & $\begin{array}{c}\text { Propo- } \\
\text { rtion }\end{array}$ & $\begin{array}{l}\text { Num- } \\
\text { ber }\end{array}$ & $\begin{array}{l}\text { Propo } \\
\text {-rtion }\end{array}$ & $\begin{array}{c}\text { Num } \\
\text {-ber }\end{array}$ & $\begin{array}{c}\text { Propo- } \\
\text { rtion }\end{array}$ & $\begin{array}{l}\text { Num } \\
\text {-ber }\end{array}$ & $\begin{array}{l}\text { Propo- } \\
\text { rtion }\end{array}$ & $\begin{array}{c}\text { Numb } \\
-e r\end{array}$ & $\begin{array}{c}\text { Propo- } \\
\text { rtion }\end{array}$ \\
\hline SOC1 & 63 & 21 & 120 & 40 & 99 & 36 & 9 & 3 & 0 & 0 \\
\hline SOC2 & 72 & 24 & 126 & 42 & 99 & 33 & 3 & 1 & 0 & 0 \\
\hline SOC3 & 60 & 20 & 126 & 42 & 102 & 34 & 12 & 4 & 0 & 0 \\
\hline SOC4 & 72 & 24 & 126 & 42 & 96 & 32 & 6 & 2 & 0 & 0 \\
\hline final exam & 75 & 25 & 126 & 42 & 99 & 33 & 0 & 0 & 0 & 0 \\
\hline $\begin{array}{c}\text { Course } \\
\text { comprehensive } \\
\text { score }\end{array}$ & 66 & 22 & 90 & 30 & 135 & 45 & 9 & 3 & 0 & 0 \\
\hline
\end{tabular}

Table 9 Pharmacology assessment in January 2013

\begin{tabular}{|c|c|c|c|c|c|c|c|c|c|c|}
\hline $\begin{array}{l}\text { Teaching } \\
\text { class }\end{array}$ & \multicolumn{2}{|c|}{$\begin{array}{c}2012 \text { nursing } \\
\text { classes 1-6 }\end{array}$} & \multicolumn{2}{|c|}{ Total students } & \multicolumn{2}{|c|}{300} & \multicolumn{2}{|c|}{$\begin{array}{l}\text { Total expected } \\
\text { learning } \\
\text { outcomes }\end{array}$} & \multicolumn{2}{|c|}{4} \\
\hline $\begin{array}{c}\text { Grade } \\
\text { NQ-Proportion }\end{array}$ & \multicolumn{2}{|c|}{$\geq 90$} & \multicolumn{2}{|c|}{$[80,90)$} & \multicolumn{2}{|c|}{$[60,80)$} & \multicolumn{2}{|c|}{$<60$} & \multicolumn{2}{|c|}{$\begin{array}{c}\text { Abnormal } \\
\text { assessment }\end{array}$} \\
\hline $\begin{array}{l}\text { Learning } \\
\text { outcomes }\end{array}$ & $\begin{array}{l}\text { Num- } \\
\text { b-er }\end{array}$ & $\begin{array}{l}\text { Prop- } \\
\text { ortion }\end{array}$ & $\begin{array}{l}\text { Num } \\
\text {-ber }\end{array}$ & $\begin{array}{l}\text { Propo } \\
\text {-rtion }\end{array}$ & $\begin{array}{l}\text { Num } \\
\text {-ber }\end{array}$ & $\begin{array}{c}\text { Propo- } \\
\text { rtion }\end{array}$ & $\begin{array}{l}\text { Num } \\
\text {-ber }\end{array}$ & $\begin{array}{l}\text { Propo- } \\
\text { rtion }\end{array}$ & $\begin{array}{c}\text { Num- } \\
\text { ber }\end{array}$ & $\begin{array}{l}\text { Proport- } \\
\text { ion }\end{array}$ \\
\hline
\end{tabular}




\begin{tabular}{|c|c|c|c|c|c|c|c|c|c|c|}
\hline SOC1 & 45 & 15 & 60 & 20 & 150 & 60 & 15 & 5 & 0 & 0 \\
\hline SOC2 & 42 & 14 & 63 & 21 & 186 & 62 & 15 & 5 & 0 & 0 \\
\hline SOC3 & 30 & 10 & 75 & 25 & 186 & 62 & 15 & 5 & 0 & 0 \\
\hline SOC4 & 42 & 14 & 63 & 21 & 186 & 62 & 15 & 5 & 0 & 0 \\
\hline final exam & 36 & 12 & 69 & 23 & 186 & 62 & 9 & 3 & 0 & 0 \\
\hline $\begin{array}{c}\text { Course } \\
\text { comprehensive } \\
\text { score }\end{array}$ & 42 & 14 & 63 & 21 & $\mathbf{1 8 3}$ & $\mathbf{6 1}$ & $\mathbf{1 2}$ & $\mathbf{4}$ & 0 & 0 \\
\hline
\end{tabular}

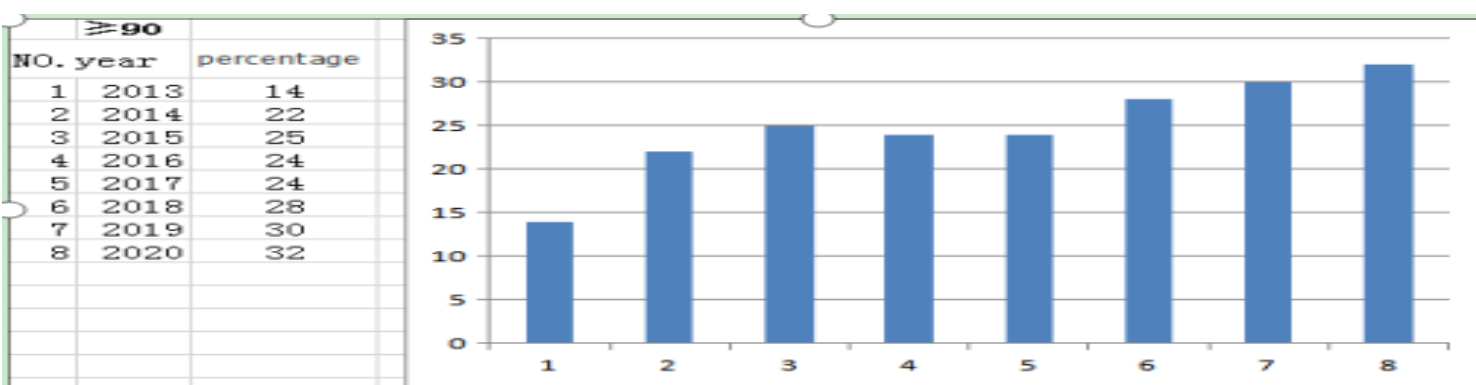

Note:The y-axis represents the percentage above 90 points; and the x-axis represents each year from 2013 to 2020.

Figure 2: Proportion of annual periodic evaluation scores above 90 from 2013 to 2020

As can be seen from Figure 2, from 2013 to 2020, the percentage of more than 90 points per year has increased year by year, from $14 \%$ in 2013 to $32 \%$ in 2020 .
From 2013 to 2020, the percentage and growth trend of $[80,90)$ are shown in Figure 3, which is also increasing year by year, from $31 \%$ in 2013 to $50 \%$ in 2020 .
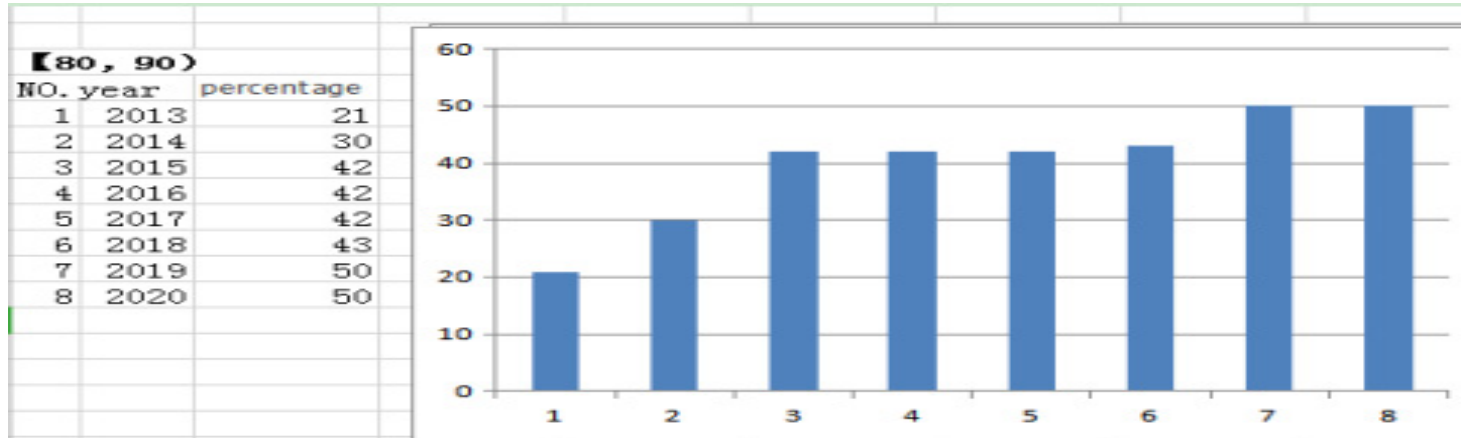

Note: the $y$-axis represents the percentage of $[80,90)$ scores, the $x$-axis represents each year from 2013 to 2020.

Figure 3: From 2013 to 2020, the percentage value of $[80,90)$ per year and the increasing trend year by year will increase from $14 \%$ in 2013 to $32 \%$ in 2020 .

The number of people with less than 60 points per year, such as figure 4 , shows that the failure rate has decreased year by year, except $4 \%$ in $2013,3 \%$ in 2014 , $1 \%$ in 2015 , and 0 from 2016 to 2020.

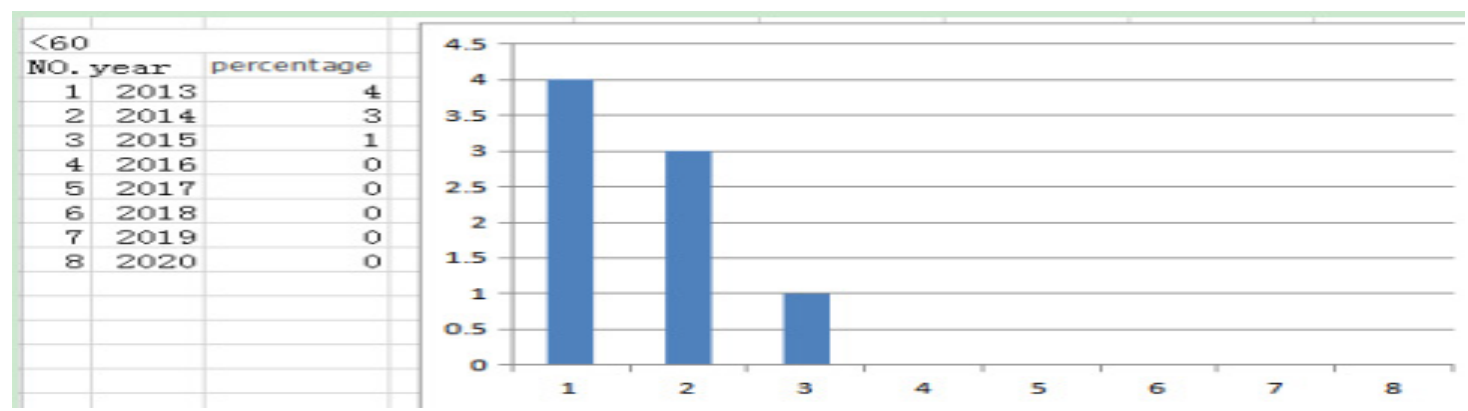

Note: the y-axis represents the failure rate, and the x-axis represents each year from 2013 to 2020.

Figure 4: Annual failure rate and change trend from 2013 to 2020

\section{Summary}

The construction and implementation of pharmacology curriculum standard based on DQP system in the United States showed that the average score, excellent rate, satisfaction with the course and students' ability were significantly improved after the implementation of DQP. At the same time, the student-oriented and student-centered classroom design has greatly improved the activity of "Pharmacology" classroom and the subjective initiative of students, which is conducive to the development of students' personality and differences, 
and the improvement of students' professional skills and comprehensive quality. At present, although DQP has been applied in more than 100 colleges and universities in the United States, it is still in the stage of exploration and experiment in China, and its integration mode and practical effect need further research and demonstration [21]. In addition, the teaching reform of DQP is not easy. It not only needs the change of relevant educational concepts, the internal teaching management system and mechanism of the school, but also needs the exploration and improvement of the teaching staff, the integration of relevant teaching resources, the strengthening of the exchange and sharing of experience between similar departments and industry experts, and the adoption of flexible teaching methods and techniques In order to meet the needs of the society and their own development, we should meet the student-centered teaching, achieve the course teaching objectives and expected learning results, so as to truly improve the students' professional ability and quality, and better meet the needs of the society and their own development needs

Pharmacology teaching has many contents and limited time. According to the students' knowledge level and teaching content, flexible teaching mode should be adopted, and continuous exploration and innovation should be carried out to make pharmacology teaching not only conform to the development of pharmacology, but also suitable for improving students' comprehensive quality and meeting the professional and comprehensive quality requirements of students' future work. In nursing education, the orientation of higher vocational education is different from that of general undergraduate education. Pharmacology, as a basic course, should be reformed according to the characteristics of students to improve the teaching quality.

To sum up, according to the contents and characteristics of different chapters, the actual situation and learning level of students, different teaching methods and means should be selected. Teaching tasks should be reasonably arranged and teaching contents should be organically organized. It is believed that in the reform environment, pharmacology course will develop and improve with the new teaching mode.

\section{Acknowledgments}

This study was awarded the National Natural Science Foundation of China (No.41906169), natural science foundation of Guangdong Province (No.2016a0303089), fund of Guangdong Provincial Bureau of Traditional Chinese Medicine (No.20142107), natural science research fund of Medical Education Committee of Guangdong Higher Vocational College (No.2013syy26), natural Science Research Fund of Medical Education Committee of Guangdong Province (No. 2019lx025) and Natural Science Foundation of Guangdong Lingnan Institute of Technogy (No.jb201613).

\section{References}

1. $\mathrm{Xu}$ Wei. Exploration on pharmacology teaching reform of nursing specialty in Higher Vocational Colleges [J]. Chinese health industry. 2019.10: 11-13

2. Liu Cuicui, Li Xinyan, Wang Mei, et al. Practice and thinking of experimental teaching reform of Pharmacology for nursing specialty in Higher Vocational Colleges [J]. Health vocational education, 2017,35 (21): 78-79

3. Lumina Foundation. Degree Qualifications Pro-file[EB/OL].[2017-04-19].http://degreeprofile.or $\mathrm{g} /$ down load-the-dqp/2015.

4. Sun Liuyuan. DQP review of American degree qualification framework under results oriented Education $[\mathrm{J}]$ Journal of Huainan vocational and technical college, 2017.4:75-76

5. Zhao Mingyue, sun Wenli, Zhang Feng. Exploration and Research on teaching reform of nursing pharmacology in higher vocational nursing specialty [J]. Modern vocational education, 2017,12 (13): $22-24$

6. He Jing, Niu Yuqing. Exploration and practice of DQP education framework in China: a case study of business enterprise management major in Guangdong Lingnan Polytechnic. Vocational technology, 2016 (4): 13-17

7. Nie Jian, et al. Construction of food curriculum norms in Higher Vocational Colleges Based on DQP results oriented -- Taking "food safety and quality management" as an example [J]. Education observation. 2018.12:123-125

8. Ding Caijuan, ye Jingjing. Reflection on teaching reform of Pharmacology for nursing specialty [J]. Social culture analysis. 2020.5:144-148

9. Yu Shuyan. Preliminary study on practical teaching reform of nursing pharmacology in Higher Vocational Colleges [J]. Modern vocational education, 2017,25 (18): 40

10. Zhu Xiaoping. Reform of experimental teaching of nursing pharmacology to improve the quality of experimental teaching $[\mathrm{J}]$. Health vocational education, 2010, 28 (18): 111-112

11. Liu Ling, Wang Xiaoqing. Exploration and practice of higher vocational nursing pharmacology course construction $[\mathrm{J}]$. Health vocational education, 2018,9 (4): 129-130

12. Yang Jie, LV Changmo, Peng Qilun. Application of micro class, MOOC and flipped classroom in pharmacology teaching ( $\mathrm{J}$ ) . Journal of Chengdu University of traditional Chinese medicine, 2019,21 (1): $37-38$

13. Jiang Xiaoling. Exploration of surgical nursing teaching reform in Higher Vocational Colleges Based on the DQP framework of the United States [J]. Road to health. 2017.6:142

14. Chen Huifang. Research on the teaching reform of "medical microbiology and Immunology" course 
based on work integrated learning [J]. Cross strait pharmacy. October 23, 2011 (11): 225-226

15. Yin Ming, He Jing, ZHENG Jichang. Exploration and application of credit matrix structure in complete credit system reform $[\mathrm{J}]$. Contemporary vocational education. 2016, issue 6: 93-96

16. Jin Yinghui, Xing Qing, Lu Cui, et al. Research progress of surgical nursing teaching theory and method in China $[\mathrm{J}]$. Chinese nursing education, 2015, 12 (3): 230-233

17. Su Youli. Experience in improving surgical nursing teaching ( J ). Science and technology information, 2011 (7): 192-192

18. Huifang CHen. Does School Enterprise Cooperation to Promote Students' Occupation Career Planning:on the Inspirational Experience of School-enterprise Cooperation from Developed Countries[J].Review of Global Academics,Aug.2014 1.1 (2): $153-160$

19. Chen Huifang et al. Research on the application of various teaching methods in the teaching of human anatomy and physiology for pharmaceutical specialty in Higher Vocational Colleges [J]. Aviation military medicine. 12017.1:1-3

20. Zhai Shuqin, Yin Ming, ZHENG Jichang. Research on the construction of logistics management talents training curriculum system based on DQP framework [J]. China market, 2015 (11): 32-34 